\title{
Strategic Engineering Management on Performance of all Commercial Banks in Nyeri County, Kenya.
}

\author{
Vincent Kipkoech Mutai \& Dr. Anthony Osoro \\ Jomo Kenyatta University of Agriculture and Technology \\ DOI: 10.29322/IJSRP.11.10.2021.p11860 \\ http://dx.doi.org/10.29322/IJSRP.11.10.2021.p11860
}

\begin{abstract}
This research paper endeavored to establish on how strategic engineering management was affecting performance of all commercial banks in Nyeri, County, Kenya. The findings realized that commercial banks should endevour to embrace the best strategies that are aimed at propelling their banking systems with a view to satisfy their customers, increase productivity and overall enhances their profitability. Hence, when commercial banks deployed strategic engineering management occasioned through strategic implementation, strategic development, strategic planning and strategic performance of all of commercial banks in Nyeri County, Kenya was wedged.
\end{abstract}

Keywords: Strategic implementation, strategic development, strategic planning, and strategic deployment and Performance of all Commercial Banks

\subsection{Introduction:}

The development of this strategic management emphasis should not be confused with the implementation of a strategic planning process. Strategic management provides the environment that encourages the development of strategic concepts (Alshatti, 2015). However, just as strategic concepts do not usually develop spontaneously, the existence of a strategic management environment does not guarantee that commercial bank members will focus on developing strategic concepts. To encourage this focus, numerous academic and business writers have proposed various strategic planning models (Kang'oro, 2016). These strategic planning models provide specific instructions for approaching, executing, and evaluating the development of strategic concepts. For example, a common model emphasizes the need for a commercial bank to: build a strategic planning team; set the strategic planning objectives; gather member input; synthesize the developed ideas; develop an implementation plan; execute the plan; and evaluate the success of the ideas prior to the start of the next strategic planning time frame. Similar to any topic that focuses on procedural processes, the number of strategic planning methods is increasing at a rate that sometimes appears to be exponential. As such, the strategic planning process is slowly becoming synonymous with the entire field of strategy. This connection is incorrect. The strategic planning process is one element of the overall strategy topic. Strategic planning is the focused exercise of developing strategic concepts based on the inputs provided by the seven areas of strategic management. The focus of the current study is on the implementation of strategic management practices in public and private engineering commercial banks (Ansoff, Kipley, Lewis, Helm-Stevens \& Ansoff, 2018).

\subsubsection{Statement of the Problem}

The performance of Commercial Banks in Nyeri County had been declining due to stiff competition from other financial institutions, loss of customer base to the mobile money services and growing new technology (Ombaka \& Jagongo, 2018). The innovation of lending applications and mobile banking had given room for loan defaults by customers from the main banks hence reduced performance. The government introduced interest caps to all banks, which made them not to make great profits. Due to those challenges of innovation and government regulations in the banking sector, the banks had to engineer the strategies to cope with the market 
competition (Wanjiku, 2016). Most of the banks in Nigeria faced challenges such as increase of pressure on competition due to development in technology, globalization, and demand for customers had changed. Kabiru, (2015), also explored Nigerian Banks on how their commercial banks performance was also affected by strategic engineering management factors. The research study established how innovation affected performance. In a research by Waithira Wasike and Mungai (2019), on performance strategies, implementation and strategic engineering management at commercial banks, the outcome of the research study showed that product quality affected commercial bank performance. Little had been done on influence of strategic engineering management practices on commercial banks performance in Nyeri City County, hence the study found conceptual, contextual and theoretical gaps. The study therefore sought to investigate on how Nyeri County’s commercial banks are influenced by strategic engineering management.

However, despite the merit that surrounds commercial banks in Nyeri County, Kenya, their performance of all commercial banks have been declining in recent years. Increased unhealthy competition, technological changes, government policies and changes in economic and market trends are based on the above studies, none of the studies focused on the tier three commercial banks. Most of the studies were conducted in developed countries. According to Waweru and Omwenga (2015), the studies also present a contradictory argument on the relationship between expansion strategies and commercial bank performance. This therefore puts across the need for a study to fill the gap and clear the doubt on the relationship between strategic engineering management and commercial bank performance. The current study therefore sought to answer the question; are strategic engineering as the missing factors in performance of all commercial banks in Nyeri County, Kenya.

\subsection{Stakeholder Theory}

Stakeholder theory is thought to be relevant for this study in order to understand the effect of strategic implementation on performance of all commercial banks in Nyeri County, Kenya, hence it gives a theoretical background for this study. In the past thirty years, since the publication of Edward Freeman's path-breaking book, Strategic Management: A Stakeholder Approach (Reed, 1999), a new branch in Strategic Management known as "Stakeholder Theory" has been significantly advanced and "its descriptive accuracy, instrumental power, and normative validity" have also been widely justified. As an extension of the concept of "stockholder", which for a long time has been treated as the only group to whom corporate management needs be responsive in theories and practices, the word "stakeholder" was first coined in an internal memorandum at the Stanford Research Institute in 1963, referring to "those groups without whose support the commercial bank would cease to exist" (Reed, 1999). This definition was then refined in a more neutral and comprehensive way: a "stakeholder" for an commercial bank is "any group or individual who can affect or is affected by the achievement of the commercial banks' objectives" Lefrancois (2000), and Freeman clearly stated the motivation behind the emergence of "stakeholder" is to better understand and cope with the dramatic changes of the environment for modern corporations, such as "the rise of globalization, the dominance of information technology, the liberalization of states, especially the demise of centralized state planning and ownership of industry, and increased societal awareness of the impact of business on communities and nations" (Ajzen, 2012).Edward Freeman introduced it in 1963. Originally, the stakeholder concept was defined to include those persons who without their support a company would cease to exist (Jensen \& Meckling, 1976). A stakeholder analysis process was defined by Ajzen (2012) as a process of helping in the understanding of the interaction between stakeholder and a project. The stakeholder analysis was a tool that helped members of the project categorize and give priority to stakeholders playing a crucial role in project success.

\subsection{Cognitive Theory of Development}

Cognitive Theory of Development is thought to be relevant for this study in order to understand the effect of strategic development on performance of all commercial banks in Nyeri county, Kenya, hence it gives a theoretical background for this study. Also according to Armitage and Conner (1999), cognitive theory was 
developed by psychologist Jeane Peagit and it explains how a person thought processes develops from an early stage of life. The theory also looks at how these thought processes affects the way the people perceives and interacts with the world. The theory proposes four stages of development in a person's mind and how each stage influences the relationship between the person and the environment (Hunt \& Morgan, 1995). This theory is important in explaining the development of mobile banking in Kenya where the system grew step-by-step from a concept least understood until now that has reached revolutionary levels. It is a process that has grown through the stages of cognitive theory of development. The theory can also be used to explain further developments in future since mbanking concept seems to have a long life ahead. The theory is further important to this study since it explains how both commercial banks and their customers accepts the concept of mobile banking in improving the overall performance and efficient service to the customers (Ajzen, 2012).

\subsection{Strategic Management Theory}

Strategic management theory is thought to be relevant for this study in order to understand the effect off strategic planning on performance of all commercial banks in Nyeri County, Kenya, hence it gives a theoretical background for this study. Porter first introduced strategic Management Theory in 1960. The theory gives direction on strategic management practices. The theory informs objective one and four of the study, which deals with strategic planning and customer, focus by providing guidelines on strategic planning and strategic thinking (Reed, 1999). It states that strategic management incorporates the concepts of strategic planning and strategic thinking. The theory stresses the need for diverse management practices and perspectives being integrated to ensure set goals and objectives are attained in the context of the ever growing and competitive world economy. The theory directs that companies should make long-term goals by assessing potential futuristic opportunities and threats. An organization is also supposed to develop the capabilities of gaining a competitive advantage against its competitors by mobilizing their 14 resources and allocating the resources strategically. The theory majorly focusses on what measures companies can make now to bring about a desirable future performance (Lefrancois, 2000). The theory provides direction by giving guidance to companies on how they can strategically specify their objectives, come up with policies and company culture, and develop ways of achieving the goals and objectives by tapping on their available resources. According to Hunt and Morgan, (1995), three major principles have to be incorporated in strategic management practices to facilitate the success of the organization, the first principle is to ensure the organization creates for itself a position in the market that is both unique and valuable at the same time, the second principle for organizations to decide on what not to do in order to make trade-offs. The third principle states that organizations should create fit, by aligning their activities together in a way that they support the chosen strategy. The theory has been critiqued in that it overly constrains managerial discretion in an environment that is very dynamic (Reed, 1999). The theory was relevant to this particular study as it connected with the study objectives, giving guidance on how managers can incorporate strategic management practices for improved performance of their organizations.

\subsection{Delegated Monitoring Theory}

Delegated Monitoring theory is thought to be relevant for this study in order to understand how strategic deployment affects performance of all commercial banks in Nyeri county, Kenya, hence it gives a theoretical background for this study. A ccording to Reed (1999), this theory is based on two premises namely diversity of the investment projects, that explains why it is more advantageous to delegate monitoring towards an intermediary than to have it be performed individually by creditors; and secondly, intermediaries who perform the monitoring of debtors are bigger which allows them to finance a large number of debtors. This theory is important to this study in that it explains the reason why commercial banks exist. It aids in understanding why commercial banks need to focus on very particular goals given that they are just agents. The banks, like any other business, go to any length to ensure that it lives to fulfil their purpose of being established. In the context of this study, (Ajzen, 2020) the reason why the commercial banks have to incur exceeding high costs in order to ensure customer satisfaction and enhance their performance can be explained by this theory.

This publication is licensed under Creative Commons Attribution CC BY.

http://dx.doi.org/10.29322/IJSRP.11.10.2021.p11860

WWW.ijsrp.org 


\subsection{Theory of Performance}

The theory of performance is thought to be relevant for this study in order to understand the effect performance for all commercial banks in Nyeri county, Kenya, hence it gives a theoretical background for this study. According to Reed (1999) the Theory of Performance (ToP) develops and relates six foundational concepts (italicized) to form a framework that can be used to explain performance as well as performance improvements. To perform is to produce valued results. A performer can be an individual or a group of people engaging in a collaborative effort. Developing performance is a journey, and level of performance describes location in the journey. Current level of performance depends holistically on six (6) components: context, level of knowledge, levels of skills, level of identity, personal factors, and fixed factors. Three axioms are proposed for effective performance improvements. These involve a performer's mindset, immersion in an enriching environment, and engagement in reflective practice Performance, as the adage goes, is a "journey not a destination (Lefrancois, 2000)." The location in the journey is labeled as "level of performance." Each level characterizes the effectiveness or quality of a performance; As a lawyer improves her level of performance, she can conduct legal research faster, more thoroughly, and more in-depth; As an academic department improves its level of performance, Christopher (2009) the members of the department are able to produce more effective student learning, more effective research, and a more effective culture; As a manager advances his level of performances, he is able to organize people and resources more effectively and to get higher quality results in a shorter time; As a teacher advances his levels of performance, he is able to produce deeper levels of learning, improved levels of skill development, and more connection with the discipline for larger classes while spending less time doing this; As an actor improves his level of performance, he is able to learn parts quicker, play more varied roles, and produce an deeper and more meaningful impact on audiences. Performance advancing through levels "Level 1," "Level 2," etc. are used to characterize effectiveness of performance. That is, a person or commercial banks at Level 3 is performing better than a person or commercial bank at Level 2. Finally performing at a higher level produces results that can be classified into categories:

\subsubsection{Strategic Implementation;}

Strategy implementation is highly dependent on managerial competency, organization structure and resource capability (Cândido \& Santos, 2015). These drivers formed the basis of the current study. Cytonn Investments. (2018) noted that managerial competency is critical to successful strategy implementation. Managerial competencies refer to management's ability to provide leadership, control and direct, decision making, planning skills that are necessary for one to be able to guide an organization towards achievement of outlined objectives. Management plays a critical role in guiding the organization through the process of strategy implementation. Kotter indicates that management not only develops the necessary strategies but also guides their organizations towards implementation of the strategy by ensuring the required human and financial resources are available, and develop a strategy implementation schedule to guide the process used as a control mechanism during implementation (Dabari \& Saidin, 2015).

The strategy at business level generally is the same that the corporative strategy of the commercial bank. Action plan for the small commercial bank with only one line of business or the big commercial bank has not diversified in different products or markets. The business strategies have potential to make an impact of first order about the risk of financial accident, a direct economic consequence for the owners, and investors of the companies, Habib \& Hasan, (2017). These strategies are approaches and measurements created by the administration with the aim of producing a successful performance in a specific business line. The main importance of the business strategy consists on how to create and reinforce the competitive position of the company on a long term in the market. According to Da Silva and Mazzon (2016), different authors provide typologies that describe how companies compete in their respective market environments. Elbanna, Andrews and Pollanen (2016) labels the business strategies in terms of leadership in costs and differentiation of products; Mao, Li, Ye, and Cai, (2017) in terms of exploration and exploitation; Ehiedu (2015) in terms of operational excellence, leadership of product and trust with the client; Ferreira and Perks (2016) in terms of 
innovation to identify and explore of new products and market opportunities; and Faith (2019) they describe a methodology to formulate business strategies in small and medium manufacturing companies. These authors evaluate and generate action plans to improve the competitiveness, taking into account the owner preferences.

To implement strategies, it is important to plan a program in which employees have well-defined job descriptions and implementation tools such as technology and information systems. A suitable organizational structure together with strong visionary leadership and organizational culture can contribute towards effective strategy implementation. Ferri, Kalmi and Kerola (2015) emphasized that the relationship between strategy planning and implementation is an important matter as it can result in many positive outcomes for the commercial bank Successful implementation depends on: revolutionizing attitudes, viewpoints and future prospects; comprehensive planning; implementation commitment and efficient control tools. Figure 2.2 below shows that if these strategic drivers are in place, it may lead to successful strategy implementation.
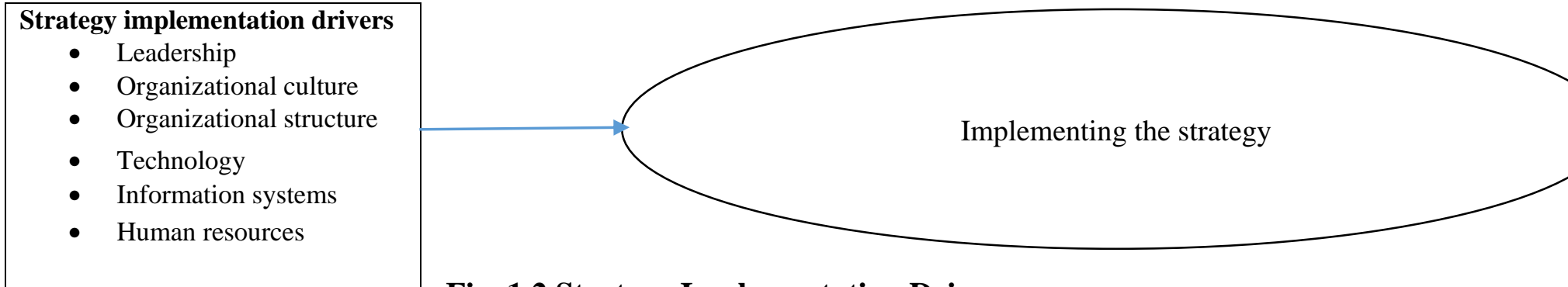

Fig. 1.2 Strategy Implementation Drivers

\subsubsection{Strategic Development;}

According to Filatotchev, Su, and Bruton (2017), any commercial bank strategy must define where the company wants to be in the future and evaluate objectively where it is now to decide how to get there; taking into account the options, alternatives, available resources, and the needed changes. A company achieves a superior profitability in its industry when achieving higher prices or lower costs than its competitors; this is achieved through the operative effectiveness or the strategic positioning (Gatuhi, 2015). For Gleeson (2018), a good strategy is a coherent set of analysis, concepts, policies, arguments, and actions that give responses to a high-risk challenge. The strategies based on the costs have been considered among the generic forms of strategic positioning (Goromonzi, 2016). According to Gure and Karugu (2018), the creation of a strategy is not only a task for the executives; on the contrary, the definition of the business approaches and new measures to initiate, involve all the hierarchy levels of the commercial bank (head of business unit, heads of products, heads of functional areas within a business or division, administrators, and supervisors). The academics and professionals are more and more interested in the concept of sustainability (integrated measure of the economic, social, and environmental performance). For Gleeson (2018), the strategies must be socially sustainable, creating value not only for the shareholder but also for the other interested, for the employees (Gure \&Karugu, 2018).

According to Radomska, (2015), the sustainability issues in the strategies are becoming a natural element of the business policies, and their actions are important for the business of the company and for the financial result, as to cost reduction, cleaner production, gas reduction, and so on, Wang, Zhong, Hao and Hou, (2018). For supply change management, the sustainability is an important issue, creating a new age of business thinking and a source of competitive advantage. In general, to create strategies, authors such as Gleeson (2018) suggest that all starts from the analysis of the environment surrounding the company, pretending with it the proposition of action plans, aimed at improving competitiveness. According to Munive-Hernandez, Dewhurst, Pritchard and Barber, (2014), in order to analyze the situation in which a company is found, the most commonly used is the SWOT analysis, which allows to determine strengths and opportunities of the company as well as the 
weaknesses and threats that the market offers in the scope of its business. According to Gure and Karugu (2018), in order for a strategy to be successful, it must be designed in the following way: simple, coherent, and long-term goals; deep knowledge of the competitive environment; objective evaluation of the resources; and effective implantation.

\subsubsection{Strategic Planning}

It is the complement of the general strategy. Its application corresponds to the leader or director. The roles of senior management and the management of organizational projects are an essential part in the effective planning of the company's strategy, Hyväri, (2016). At directive level, this strategy is used as a mean to perform various functions, serving as support in decision making and carry out coordination processes and communication of goals or the strategic purpose. Toyota Company uses 'True North' approach, a concept of lean management process that works as a compass to guide an organization from the current conditions to where they want to reach. It acts as a mission statement that reflects the purpose of the organization and the foundation of a strategic plan (Chladkova \& Formankova, 2016). According to Genoveva and Siam, (2017), any business strategy must incorporate in an effective way the concept of corporate social responsibility (CSR). According to Van der Kolk and Schokker, (2016), CSR is necessary if developing competitive advantages is wanted in the current environment. Presley, Meade and Sarkis, (2016) define CSR as a way of directing commercial bank based on the management of the impacts that its activity generates on its clients, employees, shareholders, local communities, environment, and society in general. SM implies the formulation and implementation of the main objectives and initiatives adopted by the senior managers of a company, in relation to owners, based on the consideration of the resources, and an evaluation $\mathrm{n}$ of the external and internal environment in which the commercial bank competes Rugman and Verbeke, (2017). Thus, it should have at least five attributes to be a business strategy, Vencato, Gomes, Scherer, Kneipp and Bichueti, (2014): be measurable; clarity in the objectives; resource consumption; assignment of responsible; and that it can be checked.

Companies now focus more on exploitation of external resources such as customers, rather than internal efficiency, to gain new competitive advantages. People's ideas are fed by brands, and this exercise provides the opportunity to co-create products in collaboration with customers, Cattani, Porac and Thomas, (2017). According to Gure and Karugu (2018), the application of this concept allows to analyze the relation between the degree of commercial bank structure, performance of the commercial banks, and the learning capacity of the commercial bank. For Keyes, (2016), an commercial bank with organizational learning culture improves significantly the competitive advantages, allowing to survive in a competitive world, Li and Shi, (2016); in the same way it provides improvements in the performance of the companies supported by the concept of transactional commercial bank learning, and this mechanism allows the commercial banks to keep the knowledge and transmit it to specialists for the generation or rethink of new rules (Gracia \& Quezada, 2016) analyzed the relation between self-managed work and the organizational learning capacity as indicators of performance in the improvement of the innovative capacities of the commercial banks.

\subsubsection{Strategic Deployment}

Good commercial bank structures act as moderators for improving the influence that leaders have about the behavior, performance, and work of their subordinates, in search of the satisfaction of the client, Oliveira, Nascimento, Mello and Fleury, (2016). Different authors have defined the concept of commercial bank structure. For Gleeson (2018), all are the patterns of design to organize a company, taking into account all the forms in which work is divided and the subsequent coordination of the same, searching to meet the proposed goals and to achieve the objectives set. According to Hailu and Belachew (2016), a commercial bank structure is the set of responsibilities and relations that formally determine the functions that each unit must accomplish and the way of communication between each work team. Gure and Karugu (2018) made an evaluation of how the leadership of men and women influence in the commercial bank structures, this author states that skills of 
men and women gain similar legitimacy, but when a commercial bank fails, the perception of competence of women leaders, the status, and the interpersonal skills fall more than those of men. The following are the requirements for the implementation of a commercial bank structure: hierarchy of power and authority for the establishment of responsibilities and goals, which must be verifiable, accurate, and achievable, Sun et al. (2016), for them to be precise they must be quantitative and for There must be a clear definition of the duties, rights, and activities of each person.

The area of authority of each person must be set, that everyone must do to achieve the goals, Wang, Hou and Sun, (2018). To know how and where to get the necessary information for each activity, each person must know where to get the information and it must be provided, Kamau \& Oluoch, 2016).Some elements that must be considered within a commercial bank structure are: geography: it refers to the location of the company, the nearby companies necessaries, and the geographic distribution of the areas of the commercial bank with an effective communication network, Kamukama, Kyomuhangi, Akisimire and Orobia (2017); number of employees: in order for the organization to work efficiently, it must have clearly defined the number of employees that are required, Kang and Kinyua (2016); evolution of the product: the commercial bank must evolve to the extent its product does, being able to start as a small line and then diversify as needed; distribution of the authority: it must be established if the commercial bank works in a centralized or decentralized way Kongsong, (2017); control: it refers to the requirements and regulations that must be implemented in function of the type of product that the commercial bank offers, with the purpose of complying with them and offering a competitive product; and market: the organizational structure of the commercial bank must rotate around the suppliers and the consumers, and it must have a marketing team and adequate selling force. The commercial bank created the structures to coordinate the activities of work factors and control the member performance (Kavulya, Muturi, Rotich \& Ogollah, 2018).

\subsubsection{Performance of Commercial Banks}

Performance should be determined by various factors that a commercial Banks needs to recognize so that it can ensure that they are included in the activities planned. The firm goals are defined and performance indicators established by managers in commercial Banks to ensure that commercial Banks performance is improved. The managers use a systematic approach which is effective in measuring of a commercial Banks's performance as affirmed by Kavulya et al. (2018). How performance factors relate with each other and the process of identifying them helps a commercial bank in improving its performance. There are three main areas that define organizational performance which are; the performance of its finances, performance in its product market and returns of the shareholders according to (Faith, 2019). The performance of commercial Banks's is determined by its plans of strategies, operations, finances, legal factors and the development of the commercial bank. It involves measuring of the procedure then modifying it, increasing its efficiency and effectiveness. Almost all commercial Banks practice the concept of strategy management as this helps in determination of how the commercial Banks performs.

Commercial banks Enterprise Performance Management (EPM) Suite is a software solution that offers KPIs and dashboards so customers can run their business more effectively through measuring, managing, and driving performance ( Kibet \& Sile, 2017). Commercial bank places data analytics and performance evaluation within its business context so users clearly understand results, and can place decisions into an execution framework to achieve business outcomes. The commercial bank platform is a digital toolbox that allows you to select and add solutions you need when you need them, whether you're looking to solve a single challenge or transform your business as a whole. Highly robust and feature-rich, commercial bank break down silos of data, access information on any device; desktop, tablet or mobile, to make better data-driven decisions by working with data in its context. All Commercial banks solutions are built on the platform, and are secure, scalable, easily configurable, cost-effective, quick to implement and compatible with most pre-existing tools and applications. 
The Kenyan commercial banks' performance was studied by Kihara (2017), and how it was affected by technological innovation. All the Kenyan commercial banks were targeted using descriptive cross sectional design which was employed by the study which was a census. The Central Bank of Kenya was the source for the annual financial reports which was the study's secondary data. A structured questionnaire was used in the customer care departments to collect primary data from the personnel. IBM SPSS Statistics 21.0 was used to analyze the data and frequencies, descriptive statistics and multiple regression analysis were involved in computation.

\subsection{Research Design.}

Research design is the framework of research methods and techniques chosen by a researcher (Sekaran, 2016). The design allows researchers to hone in on research methods that are suitable for the subject matter and set up their studies up for success (Zhang \& Wen, 2016). The research methodology for this study was descriptive research design, where qualitative research design was applied. When both qualitative and quantitative are applied they support each other since one uses numerical and the other one uses words (Sekara, 2016).

\subsection{Inferential Statistics Analysis}

\section{Effect of strategic Implementation on performance of all Commercial Banks in Nyeri}

The study sought to determine the effect of strategic engineering management and performance of all commercial banks in Nyeri County, Kenya. The researcher provided a five point Likerts scale choices where the respondents were to pick in the following sequence; $\mathrm{SA}=$ strongly agree, $\mathrm{A}=$ agree, $\mathrm{N}=$ neutral, $\mathrm{D}=$ disagree, $\mathrm{SD}=$ strongly disagree.

When the respondents were asked whether they agree there is enough and good implementation strategy in your reporting system. Majority $35(39.8 \%)$ of the respondents agreed, while $19(21.6 \%)$ of the respondents were neutral, also $16(18.1 \%)$ of the respondents strongly agreed, a few 10 (11.4\%) of the respondents strongly disagreed and finally $8(9.1 \%)$ of the respondents disagreed. When the respondents were asked whether they agreement that the bank has the ability and willingness to make strategic implementation processes, Majority 30 $(34.1 \%)$ of the respondents indicated they strongly agree, also $28(31.8 \%)$ of the respondents indicated they agree, while $16(18.1 \%)$ of the respondents indicated they disagree, a few $11(12.5 \%)$ of the respondents indicated they strongly disagree and the remaining $3(3.5 \%)$ of the respondents indicated they were neutral. The researcher asked the respondents to show their level of agreement about their banking system has a welldefined strategic framework system, Majority 30 (34.1\%) of the respondents agreed, while $25(28.4 \%)$ of the respondents strongly agreed, also $15(17.1 \%)$ of the respondents disagreed, a few $13(14.8 \%)$ of the respondents strongly disagreed and the remaining $5(5.6 \%)$ of the respondents were neutral. When the researcher also asked the respondents to show their level of agreement regarding the commitment of all employees working as a teamwork, Majority 27 (30.7\%) of the respondents strongly agreed, also 23 (26.1\%) of the respondents agreed, further $21(23.8 \%)$ of the respondents disagreed, a few $12(13.6 \%)$ of the respondents strongly disagreed, and finally $5(5.8 \%)$ of the respondents were neutral respectively. When the researcher asked the respondents to show in their own opinion whether they agree that the strategic implementation can have an effect on performance of all commercial banks in Nyeri County, Kenya, Majority 59 (67\%) of the respondents indicated that strategic implementation were the main constraints to most of commercial banks poor performance by ticking Yes, while the remaining 29 (33) of the respondents indicated No. When asked to explain most 65 $(73.9 \%)$ of the respondents indicated that strategic implementation being the main cause of poor performance but also there is need to have an expertise in the area of strategic engineering management so as to drive the implementation process hence continuous improvement True North. The rest $23(26.1 \%)$ of the respondents abstain from explaining. This is in line with the findings of Ombaka and Jagongo, (2018). 
Table 3.1: Effect of strategic implementation on performance of all Commercial Banks

\begin{tabular}{|c|c|c|c|c|c|c|}
\hline Statements & $\%$ & $\mathbf{S A}$ & $\mathbf{A}$ & $\mathbf{N}$ & $\mathbf{D}$ & SD \\
\hline $\begin{array}{l}\text { Do you agree there is enough and } \\
\text { good implementation strategy in } \\
\text { your reporting system }\end{array}$ & $\%$ & 18.1 & 39.8 & 21.6 & 9.1 & 11.4 \\
\hline $\begin{array}{l}\text { Are you in agreement that your } \\
\text { bank has the ability and } \\
\text { willingness to make strategic } \\
\text { implementation processes. }\end{array}$ & $\%$ & 34.1 & 31.8 & 3.5 & 18.1 & 12.5 \\
\hline $\begin{array}{l}\text { Are you in agreement that your } \\
\text { banking system has well-defined } \\
\text { strategic framework systems. }\end{array}$ & $\%$ & 28.3 & 34.1 & 5.6 & 17.1 & 14.8 \\
\hline $\begin{array}{l}\text { Are you in agreement that there } \\
\text { is commitment from all } \\
\text { employees in your bank as form } \\
\text { of teamwork. }\end{array}$ & $\%$ & 30.7 & 26.1 & 5.8 & 23.8 & 13.6 \\
\hline
\end{tabular}

\section{Strategic Development}

Effect of strategic development on Performance of all Commercial BanksThe study sought to determine the effect of strategic engineering management and performance of all commercial banks in Nyeri County, Kenya. The researcher provided a five point Likerts scale choices where the respondents were to pick in the following sequence; $\mathrm{SA}=$ strongly agree, $\mathrm{A}=$ agree, $\mathrm{N}=$ neutral, $\mathrm{D}=$ disagree, $\mathrm{SD}=$ strongly disagree.

When the respondents were asked whether they were in agreement that their process of researching can result to better performance to all commercial banks in Nyeri County, Majority 43 (49.1\%) of the respondents strongly agreed, also $32(36.4 \%)$ of the respondents agreed, a few $7(8 \%)$ of the respondents disagreed, further $4(5 \%)$ of the respondents were neutral and the remaining $2(1.5 \%)$ of the respondents strongly disagreed. When asked whether they are in agreement that their bank have identified strategic options while emphasizing better performance towards continuous improvement, Majority $40(46.2 \%)$ of the respondents strongly agreed, while $36(40.8 \%)$ of the respondents agreed, a few $7(7.9 \%)$ of the respondents were neutral, further $3(4.1 \%)$ of the respondents disagreed and the remaining $2(1 \%)$ of the respondents strongly disagreed. This echoes the finding of Olang (2017) who observed that performance is key for any investment. When the research also asked the respondents to indicate their level of agreement whether their banks has the best selecting strategic leading to the most promising performance in their future endevours, Majority $38(43.5 \%)$ of the respondents strongly agreed, while $27(31.2 \%)$ of the respondents agreed, few $8(9.1 \%)$ of the respondents were neutral, further 8 $(8.5 \%)$ of the respondents strongly disagreed and the remaining $7(7.8 \%)$ of the respondents disagreed. The researcher further asked the respondents to show their level of agreement as to whether their banks always endevours to achieve the best strategic engineering management goals for future prosperity, Majority 33 $(38.3 \%)$ of the respondents indicated that they agreed, while $28(32.1 \%)$ of the respondents indicated that they agree, a few $11(12.3 \%)$ of the respondents indicated neutral, further $9(9.7 \%)$ of the respondents indicated they strongly disagreed and the remaining 7 (7.6\%) of the respondents disagreed. This is in line with the findings of Ombaka and Jagongo, (2018).Further when the researcher asked the respondents about their own opinion on whether strategic development can have an effect on the performance of all commercial banks in Nyeri County, Kenya, most $73.2 \%$ of the respondents were in agreement ticking Yes. While $26.8 \%$ of the respondents ticked No. When asked if Yes, they explain 58.3\% of the respondents were of the opinion that strategic development is not the only tool to measure the performance in all commercial banks but there are indicators which can also impressed the level of performance such as good customer service, online services and modern technology 
towards better strategic engineering management towards achieving more returns on investment hence customer satisfaction.

Table 3.2: Effect of strategic development on performance of all Commercial Banks in Nyeri

\begin{tabular}{|c|c|c|c|c|c|c|c|}
\hline $\begin{array}{l}\text { Strategic } \\
\text { Planning }\end{array}$ & Statements & & $\mathbf{S A}$ & $\mathbf{A}$ & $\mathbf{N}$ & D & SD \\
\hline $\begin{array}{l}\text { Effect of } \\
\text { Strategic }\end{array}$ & $\begin{array}{l}\text { Are you in agreement that process researching can } \\
\text { result to better performance to all commercial banks } \\
\text { in Nyeri County. }\end{array}$ & $\%$ & 49.1 & 36.4 & 5 & 8 & 1.5 \\
\hline $\begin{array}{l}\text { planning on } \\
\text { Performance } \\
\text { all }\end{array}$ & $\begin{array}{l}\text { Are you in agreement that your bank has identifying } \\
\text { strategic options in place towards better } \\
\text { performance. }\end{array}$ & $\%$ & 46.2 & 40.8 & 7.9 & 4.1 & 1 \\
\hline $\begin{array}{l}\text { Commercial } \\
\text { Banks in } \\
\text { Nveri }\end{array}$ & $\begin{array}{l}\text { Are you in agreement that your bank has the best } \\
\text { selecting strategies leading to the most promising } \\
\text { performance in future. }\end{array}$ & $\%$ & 43.9 & 31.2 & 9.1 & 7.8 & 8 \\
\hline The study & $\begin{array}{l}\text { Are you in agreement that your bank always } \\
\text { endevours to achieve the best strategic engineering } \\
\text { management goals. }\end{array}$ & $\%$ & 32.1 & 38.3 & 12.3 & 7.6 & 9.7 \\
\hline
\end{tabular}

determine the effect of strategic planning performance of all commercial banks in Nyeri County, Kenya. The researcher provided a five point Likerts scale choices where the respondents were to pick in the following sequence; $\mathrm{SA}=$ strongly agree, $\mathrm{A}=$ agree, $\mathrm{N}=$ neutral, $\mathrm{D}=$ disagree, $\mathrm{SD}=$ strongly disagree.

When the respondents were asked whether they agree that in their banks they have clearly articulated the objective of strategic planning, Majority $30(34.8 \%)$ of the respondents agreed, while $29(33.2 \%)$ of the respondents strongly agreed, a few $13(14.7 \%)$ of the respondents were neutral, further $11(12 \%)$ of the respondents disagreed and the remaining $5(5.3 \%)$ of the respondents strongly disagreed. The researcher also asked the respondents whether they agree that their bank has the best planning approaches and tactics towards the improvement of commercial banks in Nyeri County, Kenya, Majority $28(32.3 \%)$ of the respondents strongly agreed, while $24(28 \%)$ of the respondents were neutral, a few $15(16.1 \%)$ of the respondents disagreed, further $14(15.7 \%)$ of the respondents agreed and the remaining 7 (7.9\%) of the respondents strongly disagreed. When the researcher also asked the respondents to indicate their level of agreement as to whether their bank have a good vision and mission statement towards embracing of internal and external customers, Majority $38(42.7 \%)$ of the respondents agreed, while $24(27.3 \%)$ of the respondents were neutral, further 22 (26\%) of the respondents strongly agreed, also $3(3.1 \%)$ of the respondents disagreed and the remaining 1 $(0.9 \%)$ of the respondents disagreed. When the respondents were to indicate whether their level of agreement whether bank overall goals always endevours to improve strategic engineering management of all commercial bank in Nyeri County, Majority $45(51.4 \%)$ of the respondents agreed, while $23(26.1 \%)$ of the respondents were neutral, further $9(9.6 \%)$ of the respondents disagreed, also $8(7.9 \%)$ of the respondents strongly disagreed and the remaining $3(5 \%)$ of the respondents strongly agreed.

Further the researcher wanted the respondent to indicate whether strategic planning has an effect on performance of all commercial banks in Nyeri County, Kenya, Majority $71.2 \%$ of the respondents ticked Yes, while $28.8 \%$ of the respondents ticked No. The researcher requested who ticked Yes to explain why they agree that strategic planning has an impact on performance of all commercial banks in Nyeri County, Kenya, nearly $69.1 \%$ all the respondents who had ticked Yes explained precisely that strategic planning is the only driver towards strategic engineering management that can be impressed to improve performance of modern 
commercial banks by being pro-active in planning strategically. Only $2.1 \%$ of the respondents abstained from explaining even though they have ticked Yes. This is in line with the findings of Nzuki (2016).

Table 3.3: Effect of strategic planning on performance in all Commercial Banks County

\begin{tabular}{|c|c|c|c|c|c|c|}
\hline Statements & & $\mathbf{S A}$ & $\mathbf{A}$ & $\mathbf{N}$ & D & SD \\
\hline $\begin{array}{l}\text { Are you in agreement that in your bank } \\
\text { you have clearly articulated objectives of } \\
\text { strategic planning. }\end{array}$ & $\%$ & 33.2 & 34.8 & 13.7 & 13 & 5.3 \\
\hline $\begin{array}{l}\text { Are you in agreement that your bank has } \\
\text { the best planning approaches and tactics } \\
\text { towards the improvement of commercial } \\
\text { banks in Nyeri County. }\end{array}$ & $\%$ & 32.3 & 15.7 & 28 & 16.1 & 7.9 \\
\hline $\begin{array}{l}\text { Are you in agreement that your bank has a } \\
\text { good vision and mission statement } \\
\text { towards impressment of your internal and } \\
\text { external customers. }\end{array}$ & $\%$ & 26 & 42.7 & 27.3 & 3.1 & 0.9 \\
\hline $\begin{array}{l}\text { Are you in agreement that your bank's } \\
\text { overall goals always endeavor to improve } \\
\text { strategic engineering management on } \\
\text { performance of all commercial banks in } \\
\text { Nyeri County. }\end{array}$ & $\%$ & 5 & 51.4 & 26.1 & 9.6 & 7.9 \\
\hline
\end{tabular}

\section{Strategic Deployment}

\section{Effect of Strategic Deployment on Performance all Commercial Banks in Nyeri County}

Respondents were asked to give their responses in regard to strategic deployment in five point Likert scale were as follows: $\mathrm{SA}=$ Strongly Agree, $\mathrm{A}=$ Agree, $\mathrm{N}=$ Neutral, $\mathrm{D}=$ Disagree, and $\mathrm{SD}=$ Strongly Disagree. The results obtained are as presented in Table 4.10 .

From table 4.10 below, the respondents concurred that their banks have clearly articulated pre-deployment strategies within their systems. Most of the respondents gave a mean (M) of 3.934 and a standard deviation (SD) of .8172 respectively; when the respondents were asked whether they are in agreement that their banks have the best movement realignment of short term leading to long term achievement of goals in strategic engineering management, most of the respondents gave a mean $(\mathrm{M})$ of 4.072 and a standard deviation (SD) of .7543 respectively; also when the respondents were asked whether they are in agreement that their banks have well cascaded goals throughout the banking systems, most of the respondents gave a mean (M) of 4.393 and a standard deviation (SD) of .7654 respectively; further when the respondents were asked whether they were in agreement that their banks always endeavors to improve both internal and external needs of their client leading to strategic engineering management in all commercial in Nyeri County, Kenya, hence high performance. Majority of the respondents gave a mean (M) of 4.028 and standard deviation (SD) of .7572 respectively; the respondents also were requested to state their level of agreement regarding their own opinion in relation to strategic deployment on performance of all commercial banks in Nyeri County, Kenya majority of the respondents gave Yes response which is equivalent to mean (M) of 4.281 and a standard deviation (SD) of .8203 respectively; when the respondents were asked if they gave Yes they explain majority of the respondents gave a mean (M) of 4.035 and a standard deviation (SD) of .9186 respectively. These findings concur with the findings of Nzuki (2016) that the goal of strategic deployment was to improve performance of all commercial 
banks in Nyeri County, Kenya. This is in line with the finding of Kothari (2011). It is essential for strategic deployment managers to comprehend the provisions of policies to be implemented towards performance of all commercial banks in Nyeri County, Kenya.

Table 3.4: Strategic Deployment

\begin{tabular}{lccc}
\hline Statement & Mean & Std. Dev. \\
\hline $\begin{array}{l}\text { Are you in agreement that in your bank you have } \\
\text { clearly articulated pre-deployment strategies. }\end{array}$ & 3.934 & .8172 \\
$\begin{array}{l}\text { Are you in agreement that your bank has the best } \\
\text { movement realignment of short term leading to }\end{array}$ & 4.072 & .7543 \\
$\begin{array}{l}\text { long term achievement of goals in strategic } \\
\text { engineering management. }\end{array}$ & \\
$\begin{array}{l}\text { Are you in agreement that your bank has well } \\
\text { cascaded goals throughout the banking systems }\end{array}$ & 4.393 & .7654 \\
$\begin{array}{l}\text { Are you in agreement that your bank's always } \\
\text { endeavoring to improve both internal and }\end{array}$ & 4.028 & .7572 \\
$\begin{array}{l}\text { external needs of your client leading to strategic } \\
\text { engineering management, hence performance of } \\
\text { all commercial banks in Nyeri County. }\end{array}$ & & \\
$\begin{array}{l}\text { In your own opinion do you agree that strategic } \\
\text { deployment has an effect on performance of all }\end{array}$ & 4.281 & \\
$\begin{array}{l}\text { commercial banks in Nyeri county, Kenya. } \\
\begin{array}{l}\text { When the respondents were asked to explain to } \\
\text { explain the results were: }\end{array}\end{array}$ \\
\end{tabular}

\section{Performance of all Commercial Banks in Nyeri County, Kenya}

Respondents were asked to give their responses in regard to performance of all commercial banks in Nyeri County, Kenya using a five point Likert scale were as follows: SA=Strongly Agree, A=Agree, N= Neutral, $\mathrm{D}=$ Disagree, and $\mathrm{SD}=$ Strongly Disagree.

These results are in table 4.11 below: when the respondents were asked whether they are in agreement that their banks have a good return on asset as a leading strategy in the area of strategic engineering management on performance of all commercial banks in Nyeri County. Majority of the respondents gave a mean (M) of 3.921 and a standard deviation ( SD) of 0.8129 respectively; also when the respondents were asked whether they are in agreement that their banks have a good return on equity as a leading strategy in the area of strategic engineering management on performance of all commercial banks in Nyeri County, Majority of the respondents gave a mean (M) of 3.094 and a standard deviation of (SD) of 0.7074 respectively; further when the respondents were asked whether they agree that their banks have a good computing cost to income ratio as a leading strategy in the area of strategic engineering management on performance of all commercial banks in Nyeri County, most of the respondents responded with a mean (M) of 4.947 and a standard deviation (SD) of 0.5972 respectively; when the respondents were asked whether they are in agreement that their banks have a good computing net interest as a leading strategy in the area of strategic engineering management on performance of all commercial banks in Nyeri County, most of the respondents gave a mean (M) of 4.716 and a standard deviation (SD) of 0.7461 respectively; finally when the respondents were asked in their level of opinion whether they are in agreement that performance can be embraced by strategic engineering management policy, most of the respondents ticked Yes with a mean (M) of 3.874 and a standard deviation (SD) of 0.8623 respectively; further when the respondents who ticked Yes were requested to justify their response, and majority of the respondents gave a mean (M) of 4.168 and a standard deviation (SD) of .6643 respectively. 
These findings are in line with the finding of Nzuki (2016), who contended that it is critical to monitor performance of all commercial banks at regular intervals so as to guarantee customer satisfaction and continuous improvement in the banking sector hence, more return on investment. These include recognizing the importance of strategic engineering management in the area of financial performance as a Key Performance Indicators (KPIs), also to implement the True North of strategic management goal.

Table 3.5: Performance of all Commercial Banks in Nyeri County

\begin{tabular}{|c|c|c|}
\hline Statement & Mean & Std. Dev. \\
\hline $\begin{array}{l}\text { Are in agreement that your bank has a good } \\
\text { return on asset as a leading strategy in the area of } \\
\text { strategic engineering management on } \\
\text { performance of all commercial banks in Nyeri } \\
\text { County. }\end{array}$ & 3.921 & .8129 \\
\hline $\begin{array}{l}\text { Are in agreement that your bank has a good } \\
\text { return on equity as a leading strategy in the area } \\
\text { of strategic engineering management on } \\
\text { performance of all commercial banks in Nyeri } \\
\text { County.. }\end{array}$ & 3.094 & .7074 \\
\hline $\begin{array}{l}\text { Are in agreement that your bank has a good } \\
\text { computing cost to income ratio as a leading } \\
\text { strategy in the area of strategic engineering } \\
\text { management on performance of all commercial } \\
\text { banks in Nyeri County. }\end{array}$ & 4.947 & .5972 \\
\hline $\begin{array}{l}\text { Are in agreement that your bank has a good } \\
\text { computing net interest as a leading strategy in } \\
\text { the area of strategic engineering management on } \\
\text { performance of all commercial banks in Nyeri } \\
\text { County. }\end{array}$ & 4.716 & .7461 \\
\hline $\begin{array}{l}\text { In your own opinion performance can be } \\
\text { enhanced by strategic engineering management }\end{array}$ & 3.874 & .8623 \\
\hline $\begin{array}{l}\text { When the respondents were requested to explain } \\
\text { if they indicated Yes }\end{array}$ & 4.168 & .6643 \\
\hline
\end{tabular}

\section{Regression Analysis}

To establish the degree of effect of strategic engineering management for a regression analysis was conducted, with the postulation that: variables are normally dispersed to avoid distortion of associations and significance tests, which was achieved as outliers were not identified; a linear relationship among the independent and dependent variables for accurateness of approximation, which was attained as the standardized coefficients were used in clarification. The expression of multiple regression model was as follows:

$Y=\alpha+\beta_{1} X_{1}+\beta_{2} X_{2}+\beta_{3} X 3+\beta_{4} X_{4}+\varepsilon$

Performance of all commercial banks $=\alpha+\beta_{1}$ (strategic implementation) $+\beta_{2}$ (strategic development) $+\beta_{3}$ (strategic planning) $+\beta_{4}$ (strategy development + error term. 
Regression analysis produced the coefficient of purpose and analysis of variance (ANOVA). Analysis of variance was completed to show whether there is a significant mean variance among dependent and independent variables. The ANOVA was conducted at $95 \%$ confidence level.

\subsection{Model of Goodness Fit}

Regression analysis was used to create the strengths of relationship among the performance of all commercial banks (dependent variable) and the predicting variables; strategic implementation, strategic development, strategic planning and strategic deployment (independent variables). The results showed a correlation value (R) of 0.756 which shows that there is a good linear dependence between the independent and dependent variables. These findings concur with the findings of Saunders et al., (2014). These findings are in tandem with the findings of Ombaka and Jagongo (2018), who observed that this also depicted the significance of the regression analysis done at $95 \%$ confidence level. This implies that the multiple regression model was important and can thus be used to assess the relationship among the dependent and independent variables. This echoes the findings of Nzuki (2016), who detected that analysis of variance statistics scrutinizes the differences among group means and their related procedures.

Table 3.6 Model Goodness of Fit

\begin{tabular}{llll}
\hline $\mathbf{R}$ & $\mathbf{R}^{2}$ & Adjusted $\mathbf{R}$ & Std. Error of the Estimate
\end{tabular}

\section{$\begin{array}{llll}0.756 & 0.787 & 0.719 & 0.069\end{array}$}

a. Predictors: (Constants), strategic implementation, strategic development, strategic planning and strategic deployment b. Dependent Variable: performance of all commercial bank

With an R-squared of 0.787, the model shows that strategic implementation, strategic development, strategic planning and strategic deployment can boast up to $78.7 \%$ of the differences on performance of commercial banks while $21.3 \%$ is explained by other indicators which are not inclusive in this study or model. A measure of goodness of fit synopses the discrepancy between observed values and the values anticipated under the model in question. This is in line with the findings Cherotich (2014).

\section{Summary}

The study summarizes that all commercial banks requires strategic implementation in order to implement strategic reporting, have the ability and willingness to embrace change and define a strategic framework to guide the performance all commercial banks in the County of Nyeri. The study also established that through strategic implementation commercial banks have been able to make rational decisions on priority and nonpriority policies. Strategic development was ensure mutual satisfaction to customers, through developing commercial banks strategies that are able to meet the required quality and demands dynamic of time, budget and scope of commercial banks. strategic planning was critical to monitoring the performances of all commercial banks at all level and provided a define directions that ensured that all functions were within the stipulated budget and that all tasks were met at the right time with minimal risks of failure, Strategic planning tool played critical role in achieving better performances of all commercial banks in Nyeri County, Kenya through ensuring that significant corrective actions, commercial banks appraisal, assessment tools were developed in time in order to achieve better performances of all commercial banks as they implement predeployment, movement re-alignment and cascading their goals throughout in the banking systems in order to maintain their objective towards the True North.

\section{REFERENCES}

Abashe, A. (2016). Influence of Strategic Leadership in Strategy Implementation in Commercial Banks: A Case Study of Kenya Commercial Bank . Doctoral dissertation,United States International University-Africa. 
Alade, A. O., \& Ehigbochie, J. O. (2019). Understanding the effects of strategic business management on small and medium scale enterprises for enhanced productivity in Nigeria. Management, 7(2), 60-67.

Alshatti, A. (2015). Effect of liquidity management on the profitability of Jordanian. Commercial banks. . International Journal of Business and Management, , 10(1): 62-71.

Ansoff, H. I., Kipley, D., Lewis, A. O., Helm-Stevens, R., \& Ansoff, R. (2018). Implanting strategic management. Springer.

Antill, I. (2014). Analysis of cost and schedule performance of international development projects. International journal of project management, 28(1), 68-78.

A. Habib and M. M. Hasan, "Business strategy, overvalued equities, and stock price crash risk," Research in International Business and Finance, vol. 39, pp. 389-405, 2017. View at: Publisher Site | Google Scholar

Ajzen, I. (2012). The theory of planned behavior. In P. A. M. Lange, A. W. Kruglanski, \& E. T. Higgins (Eds.), Handbook of theories of social psychology (Vol. 1, pp. 438-459), England: Sage. Crossref Google Scholar

Ajzen, I. (2020). The Theory of Planned Behavior: A Bibliography. https://people.umass.edu/aizen/tpbrefs.html Google Scholar

A. M. Rugman and A. Verbeke, Global Corporate Strategy and Trade Policy, vol. 12, Routledge, New York, NY, USA, 2017.

A. Pratiwi, W. Sutopo, R. Zakaria, and A. M. Rasli, "Formulating strategy through QSPM based on SWOT framework: a case study spin-off company in Malaysia," Advanced Science Letters, vol. 23, no. 9, pp. 8646-8651, 2017.View at: Publisher Site | Google Scholar

A. Presley, L. Meade, and J. Sarkis, "A strategic sourcing evaluation methodology for reshoring decisions," Supply Chain Forum: An International Journal, vol. 17, no. 3, pp. 156-169, 2016.View at: Publisher Site | Google Scholar

ATE, D. O. (2018). Implementation of expansion strategy at KCB group public limited company, Kenya (Doctoral dissertation, School Of Business, University Of

Nairobi).

A. Azarnivand and M. E. Banihabib, "A multi-level strategic group decision making for understanding and analysis of sustainable watershed planning in response to environmental perplexities," Group Decision and Negotiation, vol. 26, no. 3, pp. 629-648, 2017.View at: Publisher Site | Google Scholar

Armitage, C. J., \& Conner, M. (1999). The theory of planned behaviour: Assessment of

predictive validity and 'perceived control. British Journal of Social Psychology, 38(1), 35- 54.Wiley Online Library Web of Science ${ }^{\circledR}$ Google Scholar

Banafa, A., Muturi, W., \& Ngugi, K. (2015). The Impact of Leverage on Financial Performance of Listed Non-Financial Firm in Kenya. International Journal of Finance and Accounting, , 4 (7): 1-20.

Barus, J. J., Muturi, W., Kibati, P., \& Koima, J. (2017). Effect of Management Efficiency on Financial Performance of Savings and Credit Societies in Kenya. Journal of Strategic Management,, 2(1), 92-104.

Bentley, K. A., Omer, T. C., \& Sharp, N. Y. (2013). Business Strategy, Financial Reporting Irregularities, and Audit Effort. Contemporary Accounting Research, 30, 642-665.

Bento, A., Bento, R., \& White, L. F. (2014). Strategic performance management systems: Impact on business results. Journal of Computer Information Systems, 24, 25-33.

Bhattacharya, Sudipto, and Anjan V. Thakor. "Contemporary Banking Theory," Journal of Financial Intermediation, vol. 3 (October 1993), pp. 2-50.

B. Haynes, N. Nunnington, and T. Eccles, Corporate Real Estate Asset Management: Strategy and Implementation, Taylor \& Francis, Abingdon, UK, 2017.

B. Van der Kolk and T. Schokker, "Strategy implementation through hierarchical couplings in a

management control package: an explorative case study," Journal of Management Control, vol. 27, no. 2-3, pp. 129-154, 2016.View at: Publisher Site | Google Scholar

Cândido, C. J., \& Santos, S. P. (2015). Strategy implementation: What is the failure rate?. . Journal of Management \& Organization, , 21(2), 237-262.

Castanier, C., Deroche, T., \& Woodman, T. (2013). Theory of planned behaviour and road

violations: The moderating influence of perceived behavioural control. Transportation Research Part F: Traffic Psychology and Behaviour, 18, 148- 158.

Crossref Web of Science ${ }^{\circledR G o o g l e ~ S c h o l a r ~}$

Carter, "The age of strategy: strategy, organizations and society," Business History, vol. 55, no.

7, pp. 1047-1057, 2013.View at: Publisher Site | Google Scholar

This publication is licensed under Creative Commons Attribution CC BY.

http://dx.doi.org/10.29322/IJSRP.11.10.2021.p11860

WWW.ijsrp.org 
CBK. (2016). Annual Banking Industry Supervision Report. Central Bank of Kenya.

Central Bank of Kenya. (2017). Annual Banking Industry Supervision Report. Nairobi, Kenya: CBK.

Cytonn Investments. (2018). Kenya Listed Commercial Banks Analysis: Cytonn Q3'2018

Banking Sector Report. Nairobi: Cytonn.

C. Carter, "The age of strategy: strategy, organizations and society," Business History, vol. 55, no. 7, pp. 1047-1057, 2013.View at: Publisher Site | Google Scholar.

C. Hill, G. Jones, and M. Schilling, Strategic Management: Theory, Cengage Learning, Stamford, CT, USA, 11th edition, 2014.

Cho, H., \& Pucik, V. (2015). Relationship between innovativeness, quality, growth, profitability, and market value. Strategic Management Journal, 26(6), 555-570.

C. I. Setiawati and A. C. Wahyono, "Purposing division strategy for pharmaceutical producer

Dexa Medica in the demanding market," International Journal of Learning and Change, vol. 9, no. 4, pp. 367-383, 2017.View at: Publisher Site | Google Scholar.

C. Soosay, B. Nunes, D. J. Bennett, A. Sohal, J. Jabar, and M. Winroth, "Strategies for sustaining manufacturing competitiveness," Journal of Manufacturing Technology Management, vol. 27, no. 1, pp. 6-37, 2016.View at: Publisher Site | Google Scholar

C. Vencato, C. Gomes, F. Scherer, J. Kneipp, and R. Bichueti, "Strategic sustainability management and export performance," Management of Environmental Quality An International Journal, vol. 25, no. 4, pp. 431-445, 2014. View at: Google Scholar

Cherotich, R.J. (2014). Contract Management Practice And Operational Performance Of State Corporations In Kenya. Unpublished Thesis, UoN.

Christopher L. (2009). Towards a "theoretical toolbox" for strategic sourcing. Supply Chain Management: An International Journal, 14(1): 3-10. CIPS(2007). Contract Management Guide.

D. Mackay and M. Zundel, "Recovering the divide: a review of strategy and tactics in business and management," International Journal of Management Reviews, vol. 19, no. 2, pp. 175-194, 2016.

Dabari, I. J., \& Saidin, S. Z. (2015). Determinants influencing the implementation of

enterprise risk management in the Nigerian banking sector. International Journal of Asian Social Science, , 5(12), 740754.

Da Silva, E. C., \& Mazzon, J. A. (2016). Developing social marketing plan for health promotion. International Journal of Public Administration, 39(8), 577-586.

Douglas, D. (2003). Inductive theory generation: A grounded approach to business inquiry. Electronic journal of business research methods, 2(1), 47-54.

Eisenhardt, K. (1989) Agency theory: An assessment and review, Academy of Management Review, 14: 57-74.

Ehiedu, V. (2015). The impact of liquidity on the profitability of some selected companies. The Financial Statement Analysis (FSA) Approach. The International Institute of Science and Technology and Education (IISTE),, 5(5): 72-80.

Elbanna, S., Andrews, R., \& Pollanen, R. (2016). Strategic planning and implementation

success in public service organizations: Evidence from Canada. Public Management Review, , 18(7), 1017-1042.

Faith, N. (2019). Effect of expansion strategies on performance of insurance Industry in Kenya (Doctoral dissertation, Maseno University).

Ferreira, D., \& Perks, S. (2016). The influence of the political climate on South Africa's tourism industry. In The 2016 International Academic Research Conference in London-Zurich.

Ferri, G., Kalmi, P., \& Kerola, E. (2015). Organizational structure and performance in European Banks: A reassessment. . Emerald Group Publishing Limited., pp. 109-141.

Filatotchev, I., Su, Z., \& Bruton, G. D. (2017). Market orientation, growth strategy, and firm performance: the moderating effects of external connections. Management and Organization Review, 13(3), 575-601.

Ferreiro, L.D. (2013). Teach the 'Why' of Engineering: Historical Analysis is Essential for Leadership, PrismMagazine.Org.

G. Cattani, J. F. Porac, and H. Thomas, "Categories and competition," Strategic Management Journal, vol. 38, no. 1, pp. 64-92, 2017.

G. Cattani, J. F. Porac, and H. Thomas, "Categories and competition," Strategic Management Journal, vol. 38, no. 1, pp. 64-92, 2017.View at: Publisher Site | Google Scholar 
G. Cokins, Strategic Business Management: From Planning to Performance, John Wiley \& Sons, New York, NY, USA, 2017.

G. Genoveva and S. T. Siam, "Analysis of marketing strategy and competitive advantage," International Journal of Economic Perspectives, vol. 11, no. 1, pp. 1571-1579, 2017.View at: Google Scholar

Gatuhi, S. K. (2015). Macroeconomic factors and stock performance In Kenya.

Gichuki, C. W. (2014). Effect of cost management strategies on the financial performance of manufacturing companies listed on the Nairobi securities exchange.

G. Jamali, E. Karimi Asl, S. Hashemkhani Zolfani, and J. Šaparauskas, "Analysing larg supply chain management comoptitive strategies in iranian cement industries," E+M Ekonomie a Management, vol. 20, no. 3, pp. 70-83, 2017.View at: Publisher Site Google Scholar

Gleeson, P. (2018). Advantages \& Disadvantages of Matrix Organizational Structures in Business Organizations.

Goromonzi, W. O. (2016). Organizational culture, strategy implementation and commercial bank performance in Zimbabwe. . International Review of Management and Marketing, , 6(2), 307-316.

Gure, A. K., \& Karugu, J. (2018). Strategic management practices and performance of small and micro enterprises in Nairobi City County, Kenya. International Academic Journal of Human Resource and Business Administration, 3(1), 126.

Goldratt, E.M. (2017). What is this thing called the Theory of Constraints? North River Press, Croton-on-Hudson, NY. Guo, J., Liu, Z. Y., \& Peng, T. (2017). The Impact of Bank Loans on Corporate Risk-Taking: Promote or Inhibit? Accounting Research, No. 2, 42-48 + 96.

Habib, A., \& Hasan, M. M. (2017). Business Strategy, Overvalued Equities, and Stock Price Crash Risk. Research in International Business and Finance, 39, 145

Hailu, S., \& Belachew, M. (2016). Core Banking System Implementation Framework: the Case of Ethiopia. . HiLCoE Journal of Computer Science and Technology, , 3(2), 57-64.

H. Chladkova and S. Formankova, "Strategy for SMEs in the area of primary agricultural production," Agricultural Economics, vol. 62, no. 9, pp. 395-406, 2016. View at: Google Scholar

H. D. Mohammadian, Principles of Strategic Planning, Fachhochschule des Mittelstands, Bielefeld, Germany, 2017.

Heise, W., Czuchry, A., Byrne, T. (2013). Partnerships Between the International Business and Academic Communities: A Strategic Tool for Achieving Corporate Global Sustainability. Journal of Current Research in Global Business, 16(26), pp. 11-24,

Hunt, S. D., \& Morgan, R. M. (1995). The comparative advantage theory of competition. Journal of Marketing, 59(2), 115.

H. Mintzberg, The Rise and Fall of Strategic Planning: Reconceiving Roles for Planning, Plans, Planners, Free Press, New York, 2013.

H. Hyväri, "Roles of top management and organizational project management in the effective company strategy implementation," Procedia - Social and Behavioral Sciences, vol. 226, pp. 108-115, 2016.View at: Publisher Site | Google Scholar

Jensen, M., \& Meckling, W. (1976). Theory of the firm: Managerial behavior, agency costs, and ownership structure. Journal of Financial Economics, 3(4), 305-360.

J. F. Chang, Business Process Management Systems: Strategy and Implementation, Taylor \& Francis Group, New York, NY, USA, 2016.

J. Keyes, Implementing the IT Balanced Scorecard: Aligning IT with Corporate Strategy, Taylor \& Francis Group, New York, NY, USA, 2016.

J. Peppard and J. Ward, The Strategic Management of Information Systems: Building a Digital Strategy, John Wiley \& Sons, Hoboken, NJ, USA, 2016.

J. Radomska, "The concept of sustainable strategy implementation," Sustainability, vol. 7, no. 12, pp. 15847-15856, 2015.View at: Publisher Site | Google Scholar

Kabiru, M. (2015). Effect of business process reengineering factors on organizational performance of Nigerian banks: information technology capability as the moderating factor. International Journal of Business and Social Science, 2(13).

Kamau, D., \& Oluoch, J. (2016). Relationship Between Financial Innovation and Commercial Bank Performance in Kenya. International Journal of Social Sciences and Information Technology,, II(Iv), 576-594.

Kamukama, N., Kyomuhangi, D. S., Akisimire, R., \& Orobia, L. A. (2017). Competitiveadvantage: Mediator of managerial competence and financial performance of commercial banks in Uganda. . African Journal of Economic and Management Studies, , 8(2), 221-234. 
Kang, J., \& Kinyua, A. R. (2016). Effect of Internal Control System on financial performance of Companies Quoted in the Nairobi Security Exchange. . Jomo Kenyatta University of Agriculture and Technology.

Kang'oro, V. (2016). The State of Strategic management practices in public sector organizations in Kenya. International Journal of strategic management; 9(11); 102- 129

Kavulya, P. W., Muturi, W., Rotich, G., \& Ogollah, K. (2018). Effect of customer focus strategy on the performance of saccos in Kenya. International Journal of Business Strategies, 3(1), 1-16.

Kibet, K., \& Sile, I. (2017). Effect of Organizational Culture and Staff Competence on the Implementation of Credit Scoring at Kenya Women Fund Trust. . Journal of Human Resource \& Leadership,, 1(1), 25-37.

Kihara, M. P. (2017). Influence of strategy implementation on the performance of manufacturing small and medium firms in Kenya. Doctoral dissertation, COHRED, JKUAT.

Kinyanjui, J.N., Gakuu, C.M. and. Kidombo, H.K. (2015) monitoring and Evaluation Skills, Performance Contracting System and Organizational Performance in Government Ministries in Kenya. International Journal of Scientific and Research Publications, 5(7).

Kimeu, R. M., \& Maina, S. (2018). Strategy implementation and performance of commercial banks in Machakos County, Kenya. . International Academic Journal of Human Resource and Business Administration, , 3(1), 434-450.

Kusters, N. (2019). Certification for sustainable Tourism in Kenya and wider Africa.

Kongsong W. (2017). The Effect Of Contract Planning On Construction Project Performance. International Journal of Applied Engineering Research, 12(23), 13310-13313.

Langevoort, D.C. (2016). Internal Controls After Sarbanes-Oxley: Revisiting Corporate Law's Duty of Care as Responsibility for Systems. Georgetown Law Library. Available on http://scholarship.law.georgetown. edu/facpub/144 Lefrancois, G. R. (2000). Theories of Human Learning: What the old man said (4th edition). California: Wadsworth. Li, D.-y., \& Liu, J. (2014). Dynamic capabilities, environmental dynamism, and competitive advantage: Evidence from China. Journal of Business Research, 67 (1), 2793-2799.

Liu, M. X., \& Li, L. E. (2019). Strategic Differences, Financial Flexibility and Operating Performance Fluctuations. Journal of Shanxi University of Finance and Economics, 41, 80-92.

Li, Z. G., \& Shi, X. W. (2016). Strategic Differences, Management Characteristics and Bank Loan Contracts: Based on the Perspective of Risk-Taking. Journal of Zhongnan University of Economics and Law, No. 2, 68-77 + 159.

Locke, E. A., \& Latham, G. P. (1990). A theory of goal setting and task performance. Englewood Cliffs, NJ: PrenticeHall.

L. Oliveira, P. T. S. Nascimento, A. M. Mello, and A. Fleury, "Costs and benefits of following cost strategies in value chains," in Proceedings of the IEEE Portland International Conference on Management of Engineering and Technology (PICMET), pp. 501-509, Portland, OR, USA, September 2016.View at: Google Scholar

L.-T. Lu, "Strategic planning for Xiaomi: smart phones, crisis, turning point," International Business Research, vol. 10, no. 8, p. 149, 2017. View at: Publisher Site | Google Scholar.

Macharia, R. N., \& Makhamara, F. H. (2019). Strategic Planning and Organization Planning in the Ministry of Foreign Affairs in Kenya. International journal of strategic management, 8(10), 1-17.

Maina, E. W. (2018). Influence of Strategic Management Practices on Competitiveness of Kenyan Tea (Doctoral dissertation, Jkuat-cohered). 85

Mawanda, S. P., (2016). Effects of Internal Control Systems on Financial performance In an Institution of Higher Learning in Uganda: A Case of Uganda Marytrs University, retrieved at https://www.academia.edu/4812543 /effects_of_internal_control_sy stems_on_financial performance on 20th May, 2016.

M. D. Gracia and L. E. Quezada, "A framework for strategy formulation in sustainable supply chains: a case study in the electric industry," NETNOMICS: Economic Research and Electronic Networking, vol. 17, no. 1, pp. 3-27, 2016.View at: Publisher Site |Google Scholar

M. D. Pelaez, "Competitive profile matrix as a tool for evaluating strategic performance of higher education institutions," Journal of Strategy and Performance Management, vol. 4, no. 3, pp. 77-91, 2016.View at: Google Scholar

M. E. David, F. R. David, and F. R. David, "The quantitative strategic planning matrix: a new marketing tool," Journal of Strategic Marketing, vol. 25, no. 4, pp. 342-352, 2017.View at: Publisher Site | Google Scholar

M. J. Mazzei and D. Noble, "Big data dreams: a framework for corporate strategy," Business Horizons, vol. 60, no. 3, pp. 405-414, 2017.View at: Publisher Site | Google Scholar

Mbithe, E., \& Kilika, J. (2017). External environment and the implementation of customer focus strategy in Equity Bank Kenya Limited. International Academic Journal of Human Resource and Business Administration, 2(4), 282-305. McKinsey \& Company. (2018). Roaring to life: Growth and innovation in African retail banking. McKinsey \& Company.

This publication is licensed under Creative Commons Attribution CC BY.

http://dx.doi.org/10.29322/IJSRP.11.10.2021.p11860

WwW.ijsrp.org 
Mohamed, A. I., \& Bett, S. (2018). Strategic resources and performance of commercial banks in Kenya: Case of Equity Bank Limited. International Academic Journal of Human Resource and Business Administration, , 3(3), 218-242.

Moutinho, L., \& Vargas-Sanchez, A. (2018). Strategic Management in Tourism, CABI

Micheli, P., \& Mari, L. (2014). The theory and practice of performance measurement. Management Accounting Research, 25, (2), 147-156. doi: 10.1016/j.mar.2013.07.005.

M. Katsioloudes and A. K. Abouhanian, The Strategic Planning Process: Understanding Strategy in Global Markets, Taylor \& Francis, New York, NY, USA, 2016.

M. M. E. Tehrani, "Analyzing strategic factors associated with issuance of environmental liability insurance policy in developing countries using SWOT and QSPM," International Journal of Environmental Science and Development, vol. 8, no. 5, pp. 359-365, 2017. View at: Publisher Site | Google Scholar

M. M. Tahernejad, M. Ataei, and R. Khalokakaei, "A strategic analysis of Iran's dimensional stone mines using SWOT method," Arabian Journal for Science and Engineering, vol. 38, no. 1, pp. 149-154, 2013.View at: Publisher Site | Google Scholar

M. Pazouki, S. A. Jozi, and Y. A. Ziari, "Strategic management in urban environment using SWOT and QSPM model," Global Journal of Environmental Science and Management, vol. 3, no. 2, pp. 207-216, 2017.View at: Google Scholar

M. Reitzig and B. Maciejovsky, "Corporate hierarchy and vertical information flow inside the firm-a behavioral view," Strategic Management Journal, vol. 36, no. 13, pp. 1979-1999, 2015.View at: Google Scholar

Mumi, A., Joseph, G., \& Quayes, S. (2018). Organizational Structure and Performance of Microfinance Banking Institutions. . Academy of Management Proceedings , Vol. 2018, No. 1, p. 10592.

Munive-Hernandez, E. J., Dewhurst, F. W., Pritchard, M. C., \& Barber, K. D. (2014). Modelling the strategy management process: an initial BPM approach. Business Process Management Journal, 10(6), 691-711

Muteshi, D. C., \& Awino, Z. B. (2018). Strategic alliances and performance of food and beverage manufacturing companies in Kenya. DBA Africa Management Review,8(1).

Muthee, J. M. (2019). Determinants of partnership practices and performance of selected technical vocational and training education institutions in Nairobi City County, Kenya.

Mwangi, G., Gichuhi, D. M., \& Macharia, S. M. (2020). Influence of relationship management on organizational performance among insurance companies in Kenya.International Journal of Research in Business and Social Science (2147-4478), 9(1), 163-171.

Nair, A. \& Vinod R, (2015). Determinants of allocative, scale and scope efficiencies of Indian banks. Working papers 177, Indian Institute of Management Kozhikode.

N. Gotcheva, G. Watts, and P. Oedewald, "Developing smart and safe organizations: an evolutionary approach," International Journal of Organizational Analysis, vol. 21, no. 1, pp. 83-97, 2013.View at: Publisher Site | Google Scholar ,Njoroge, E. (2018). Effects of strategic planning on organizational performance: A case of event planning firms in Nairobi CBD (Doctoral dissertation, United States International University-Africa).

Nzuki, F. N. (2016).Strategic alliance and performance by Kenya commercial bank group limited (Doctoral dissertation, University of Nairobi).

O. Korableva and O. Kalimullina, "Strategic approach to the optimization of organization based on BSC-SWOT matrix," in IEEE International Conference on Knowledge Engineering and Applications (ICKEA), pp. 212-215, Singapore, September 2016.View at: Google Scholar

Omair (2014). Sample size estimation and sampling techniques for selecting a representative sample, Journal of Health Specialties, 2(4).

Ombaka, C., \& Jagongo, A. (2018). Mergers and acquisitions on financial performance among selected commercial banks, Kenya. International Academic Journal of Economics and Finance,, 3(1), 1-23.

Omesa, J. (2015). Effect of liquidity on the financial Performance of financial institutions listed at the NSE. . Unpublished MBA project, University of Nairobi.

Phillips, R. (1997). "Stakeholder theory \& a Principle of Fairness.” Business Ethics Quarterly. 7, 51-66.

P. Mao, S. Li, K. Ye, and H. Cai, "A field theory based model for identifying the effect of organizational structure on the formation of organizational culture in construction projects," KSCE Journal of Civil Engineering, vol. 21, no. 1, pp. 4553, 2017.View at: Publisher Site | Google Scholar

Rahi, S. (2015). Moderating Role of Brand Image with Relation to Internet Banking and Customer Loyalty: A Case of Branchless Banking. The Journal of Internet Banking and Commerce, 2015. 
R. D. Smith, Strategic Planning for Public Relations, Routledge, Abingdon, UK, 2013.

R. M. Grant, Contemporary Strategy Analysis: Text and Cases Edition, John Wiley \& Sons, Chichester, UK, 2016.

Ross, S. (1973). The economic theory of agency: The principal's problem. American Economic Review, 63(2), 134-139.

Robin, I., Salim, R., \& Bloch, H. (2018). Financial performance of commercial banks in the post-reform era: Further evidence from Bangladesh. . Economic Analysis and Policy, ,58, 43-54. R. Rumelt, "Good strategy/bad strategy: the difference and why it matters," Strategic Direction, vol. 28, no. 8, 2012.View at: Publisher Site | Google Scholar

Reed, D. (1999). Stakeholder management theory: A critical theory perspective. Business Ethics Quarterly, 9(3), 453483.

Saunders, M., Lewis, P., \& Thornhill, A. (2014). Research Methods for Business Students (6th Edition). Essex: Pearson Education Limited.

Sekaran. (2016). Research Methods for Business. A skill building approach, .. Sussex: John Wiley \& Sons Ltd

Shepherd, N. G. \& Rudd, J. M. (2014). The influence of context on the strategic decision-making process: A review of the literature. International Journal of Management Reviews, 16(3), 340-364. doi: 10.1111/ijmr.1202

Shah, R. (2015). U.S. Patent No. 9,072,476. Washington, DC: U.S. Patent and Trademark Office.

Sharma, P. \& Allison, J. P. (2015). The future of immune checkpointtherapy. Science, 348(6230), 56-61.

Stephenson, A, (2015). Project success: a multidimensional strategic concept. Long-Range Planning, 34, 699-725.

Sikdar, P., Kumar, A., \& Makkad, M. (2015). Online banking adoption: A factor validation and satisfaction causation study in the context of Indian banking customers. International Journal of Bank Marketing, 33(6), 760-785.

Sun, J., Wang, B. Q., Cao, F., \& Liu, X. Q. (2016). Does Corporate Strategy Affect Earnings Management? Management World, No. 3, 160-169.

Takele, Y. \& Sira, Z. (2013). Analysis of the factors influencing customers' intention to the adoption of ebanking services channels in Bahir Dar City: An integration of TAM, TPB and PR. European Scientific Journal, 9(13), 402-417. Telford, C. (2014). The intricate implementation of performance measurement systems: Exploring developments in professional-service organizations in the Dutch non-profit sector. International Review of Administrative Sciences, 74(4), pp. 615-635. International Journal of Strategic Management. Vol.10 Issue 82021

Trent, R. (2013). Strategic supply management creating the next source of competitive advantage. Ft. Lauderdale, FL: J. Ross Pub.

Umana, E. A. (2019). Conflict Resolution Strategies And Organizational Performance: An Exploratory Analysis. International Journal of Economics, Commerce and Management, United Kingdom, 7(5).

Vihari, N. S., Singh, B., \& Rao, M. K. (2016). Relationship between human capital management and organisational performance: an empirical evidence from select Indian banks. . International Journal of Learning and Intellectual Capital, , 13(1), 1-26.

Waithira, J. W., Wasike, S., \& Mungai, M. C. (2019). Tourism Product Packaging and Financial Performance of Tour Operating Companies in Nairobi. Journal of Business and Strategic Management, 4(1), 25-46.

Vyas, V., \& Raitani, S. (2014). Drivers of customers' switching behaviour in Indian banking industry. International Journal of Bank Marketing, 32(4), 321-342.

Wanjiku, M. N. (2016). The Effect Of Partnership Strategies On Performance Of Commercial Banks In Kenya (Doctoral dissertation, University Of Nairobi).

Waweru, P. K., \& Omwenga, J. (2015). The influence of strategic management practices on performance of private construction firms in Kenya. International Journal of Scientific and Research Publications,5(6), 1-36.

Wang, B. Q., Hou, C. R., \& Sun, J. (2018). Research on the Impact of Corporate Strategy on Corporate Performance. China Soft Science, No. 1, 127-137.

Wang, H. C., Zhang, X. P., Hou, C. R., \& Li, X. Y. (2017). Corporate Strategic Differences and the Cost of Equity Capital-Research on the Mediating Effect Based on Operational Risk and Information Asymmetry. China Soft Science, No. 9, 99-113.

Wang, H. C., Zhong, K., Hao, E. Q., \& Hou, C. R. (2018). Corporate Strategic Positioning and Corporate Financial Behavior: Theoretical Research Framework and Recommendations. Financial Research, No. 6, 3-13.

Wang, Y. H., \& Zhang, T. (2014). Financial Innovation, Audit Quality and Bank Risk Tolerance: Empirical Evidence from My Country's Commercial Banks. Accounting Research, No. 4, 81-87 + 96.

Ye, K. T., Dong, X. Y., \& Cui, Y. J. (2015). Corporate Strategic Positioning and the Choice of Ye, K. T., Zhang, S. S., \& Zhang, Y. X. (2014). Corporate Strategy Differences and the Value Relevance of Accounting Information. Accounting Research, No. 5, 44-51 + 94 . 
Zameer, H., Tara, A., Kausar, U., \& Mohsin, A. (2015). Impact of service quality, corporate image and customer satisfaction towards customers' perceived value in the banking sector in Pakistan. International Journal of Bank Marketing, 33(4), 442-456.

Zeinalizadeh, N., Shojaie, A. A., \& Shariatmadari, M. (2015). Modeling and analysis of bank customer satisfaction using neural networks approach. International Journal of Bank Marketing, 33(6), 717-732.

Singh, H., \& Samalia, H. (2014). A Business Intelligence Perspective for Churn

Management. Procedia - Social and Behavioral Sciences. 109, 51-56. doi: 10.1016/j.sbspro.2013.12.420

Zhang, H. L., \& Wen, T. (2016). Validity Test and Screening of Alternative Indexes of Audit Quality. Audit Research, No. 4, 67-75.

Szabo, Z. K., Šoltés, M., \& Herman, E. (2013). Innovative Capacity \& Performance of Transition Economies: Comparative Study at the Level of Enterprises. Ekonomika a manažment, 1, $52-68$. 